\title{
EMOTIONS AS THE BASIS OF LITERARY REPRESENTATIONS
}

\author{
Irana Austiningsih \\ Universitas Negeri Jember \\ irananingsih@gmail.com
}

\begin{abstract}
This article is based on the belief that elemental human motives and basic emotions provide the deep structure of literary representations, and this dep structure serves to organize the particularities of circumstances and individual indentity. Personal power and reproductive success are governing purposes in life and in literary representations. Literature and its antecedents organize experience in personally meaningful ways. They provide models of behavior and help regulate the complex cognitive machinery through which humans negotiate their school social and cultural environments. To support this analysis, a reading of a contemporary Australian writer Elizabeth Jolley's Palomino will be presented. Like of other works of the novelist, Palonimo depicts women, not Woman in the sense that female individual stands in relation to the others of the same sex. Here, one can be the multiple roles of a woman including the desires, the social struggle of the gender identity, and the basic instincts of makind. The symbolism and the literary technique used even supports the university of woman deciption in this novel.
\end{abstract}

Keywords: emotions, literary representations, Palomino.

In literature the most frequent and important themes are those that concern individual identity, sexual romance, and the family. Survival is all the basis of all adventure stories, and by far the largest propotion of stories that are not strictly oriented to survival are organized around the mating game, the concern of parents for children, and family relations generally. On the basis of such observations, one can propose a large generalization about the primacy of advanture, personal success, and romance within the themes of world literature, and this kind od generalization can in fact yield hypotheses that are restable through large-scale 
cross-cultural analysis of literary subjects (Fox, 1989; 1995). Both social and cognitive activity are a significant part of what is actually represented in literature, and they are inextricably interwined with themes of personal power and reproductives success, but in literary texts they will always have less structural importance than the more primary levels of somatic and reproductive effort. That is, most plots will be grounded more deeply in issues of personal power and love than in problems social antagonism, social affiliation, and the pursuit of knowledge about the physical and natural world.

Literature itself has until reecently been the only great repository of information about human nature. Literary authors have understood intuitively that the subject matter of literature is human experience, that experience is grounded in common natural motives and feelings, and that the common shared experience among authors, the character depicted, and the audience. Understanding the inner workings of the mind has been the heart and the soul of the literary tradition, as it no doubt was the heart and the soul of oral tradition that are the ancestors of literate cultures.

In literary structures, the idea of an individual self is indispensable to the organization literary meaning. Charachter in poems, plays, and stories are individuals and aouthors necessarily present their stories from some distinct point of view. All emotion and cognition is organized within the individual mind, and the response of audience to literary works is thus necessarily lodged in individuals, even when the response is correctively experienced, as in the audience of a play. 
One of the most import set of structures for individual identity are the five factors of personality (Digma, 1990; McCare, 1992; Bouchard, 1994; Mc. Donald, 1995). The five factors extraversions/introversions, agreebleness/antagonism, neuroticism/security, conscientiousness/carelessness, and curiosity/dullness can be used for the comparative analysis of characters, authors, and audience response. The extraversion/introversion scale measures wether the organism is more responsive to external stimuli or alternatively, more attuned to internal processes. Agreeableness and antagonism identity the two possible extremes in social interaction. They thus reflect basic principles in the hierarchy of elementary regulative principles of human behavior. Neuroticism involves an array of traits that respond to danger and that are thus signals of threat to survival both of the organism and of his/her kind and social affiliates. Conscientiousness is quality of character that is essential to personal success and to authority within a social group. Openess or intellect is a measure of responsive sensitivity to the whole range of environmental conditions, physical and social.

Individuals vary in the degree to which they are extraverted or interverted, emotionally stable or insecure, intellectually open or dull, friendly or antagonistic, and conscientious or careless, but variations in these dimensions can be likened to variations in adaptive features of the human design-for example, in keenness of eyesight or hearing, intelligence, physical strength, and sexual attractiveness. The observation of such differences is part of the common experience of everyday social interaction and evolutionary psychologist have now begun to make reasonable conjectures about the ways in which such differences can be integrated into other fundamental features of the human motivational system. Aston et.al 
(1998) correlate differences of agreebleness and emotional stability both with sex differences and with differential dispositions kin altruism and reciprocal altruism (MacDonald, 1995).

Buss (1999) argues that dimensions of personality in the five-factors system 'summarize' the most important features of the social landscape that humans have had to adapt to. This is to say that literary texts reflect an intuitive psychological understanding of human nature so literary representations can be expected to depict the ways humans perceive individual differences and integrate their perceptions into elemental motives such as mate selection strategies as can be seen for example in Jane Austen's Pride and Prejudice in which the heroine Elizabeth Bennet marries a male Darcy who is higher in status than herself and that he demonstrates his suitability as a mate in part by extending protection to her endagered kin (her system Lydia). Elizabeth undergoes a process of sorting through the personality factors, learning how to make allowances for the qualities of manner attendant on Darcy's introversion, and learning through her experience with Wickham the relatively small reliance to be placed on agreeableness when it is not accompanied by conscientiousness. In the largest thematic structure in the book, she rearranges her whole psychic economy to detach herself from her father, who is cultivated but careless, and to attach herself instead to the ethos of responsibility presented by Darcy. This psychological reorientation plays itself in the dialouge that is concerned with the functions of satire and humor, and thus with the tonal, literary dimensions that correlate with the pyschological dimensions. All of the characters in the narrative play the mating game, in accordance with sociobiological rules, but they also form a carefully constructed 
array of personality types within a pyschological economy dominated by the lead couple, and they self-consciously assess one another on the basis of verbal and imaginative styles that reflect their specific psychological constitutions.

Similar kinds of intuitive psychological depictions are integral parts of the meaning system of most fictional narratives. The specific pattern used as the elementary structure of plot in Pride and Prejudice is by no means universal but is certainly very common. It appears also, for example, in Hardy's Far From the Madding Crowd, Trollope's Can You Forgive Her?, and Tolsoy's Anna Karenina. In all of these cases, personality dimensions are not alternatives to sociobiological themes of mate selection. They are the more finely nuanced perceptions through which appropriate sexual choices are made. (For literary analyses that integrate sociobiological themes and assessment of personality within specific cultural contexts, see Carroll 1995, and Boyd 1998).

Personality factors can be used in the analysis of characters, authors, and readers. They provide points of entry into the values and sensibility of any given author and a means for assessing the evaluative response of audiences to any given author. For instance, fielding and his protagonists are robust and goodnature, sensual but friendly and open, outgoing but a little lax in their moral fiber. Rather than attempting to locate this configuration within some supposedly absolute standards of literary merit, one can instead understand that certain kinds of critical tempraments will respond to fielding with general warmth, and others, more neurotically sensitive, withdrawn and antagonistic, will find him an uncomfortable companion. 
The use of personality factors as categories of analysis need not pretend to be exhaustive. These factors can be combined with any array of significant traitsfor instance, of sex or gender, age, social class, national or ethnic identity, and cultural period. If personality dimensions are in fact part of the evolved structure of the human psyche, they provide terms that are in them selves important and that can serve as stable points of comparison. To accept the stipulation that the organizing principles of literary representations run parallel to the structure of human motives and concerns is to acceptan implication that takes one outside the range of conceptual analysis in cognitive rhetoric and brings on the psychology of emotion.

Metaphors have imaginative and specifically literary value only if they are able to engage and evoke the subjective quality of experience. Feelings are the basis of tone in literary texts and tone is the basis of generic structure. There are usually known six core emotions suggested by Ekman (1994) namely joy, sadness, anger, fear, disgust, and surprise. All of these emotions are essential components in the tonal and generic structures in literary texts. Sadness is the basis of elegy and tragedy, and happiness the basis of comedy. Surprise is essential to suspense, and anger and disgust are the animating sentiments of satires.

There are some writers who speculate that literary writing is a means of social manipulation or of sexual display (Constable, 1997). Literature is merely a means of attracting attention, enhancing prestige, and thus advancing one's reproductive prospects. It is even suggested that literature is mainly a means of fantasy fulfillment. However, this may not be the case. Literature is satisfying- 
moving or disturbing-not in the degree to which it fulfills fantasy expectationsthough it can do this-but in the degree to which it provides a sense of psychological order. It depicts order by depicting the particularities of time and place-of cultural context, individual circumstance, and personal charcater. The following part will offer an analysis of such a disturbing text written by the contemporary Australian novelist Elizabeth Jolley, Palonimo.

\section{PALONIMO AS REPRESENTING WOMAN?}

Palonimo is clearly disturbing text, not simply because of its deciption of lesbian sexuality, but because of the gap between Laura's desire and Andrea's. As the novel proceeds, one can discover that Laura's relationship with Andrea is in some way a working through of her truncated relationship with Eva, Andrea's mother. At the same time, Andrea's incestuous relationship with her brother, and the fact that she becomes pregnant by him, compromises her response to Laura's desire. The endenic side to Andrea and Laura's affair is enabled by their isolation. In the world of Laura's farm, the social pressures that distrupt and distort desire (Laura's for Eva, Andrea's for Christopher, Laura's for Esme Gollanberg) are temporarily in abeyance as once said by Laura to Andrea (p.193).

Andrea's desire for Christopher is not superseded by her affair with Laura, and her rejection by him confirms the impossibility of any fulfillment within a social context. It is worth nothing that Andrea's uninhibited desire for Christopher is disturbed within a scene of male, homosexual desire. The brother and sister stray onto a nudist beach while looking for 'place where we could be alone'. Their 
uneasiness seems misplaced until Andrea notices a schoolteacher with his changes (p.241).

He must have been school teacher with his class but it wasn't quite so straightforward you see, because just above that part of the beach was the car park overlooking the sands and the sea. We walked up there and in every car there was a man sitting and all of the were looking intently down to the bronzes school master and his class. It was as if the little boys were being paraded for these men. It was really possible to feel a sort of excitement of desire and to feel excluded from it at the same time.

This scene seems to represent a totally enclosed economy of the male gaze, directed not at the objectified female, but at small boys. Significantly this repressed memory emerges in Andrea's consciousness when she anounces her wish to leave Laura, after receiving an invitation from Irma. It is followed by an image of a ram caught in a fence, dispatced by Laura and Murphy. In this scene, Andrea watches Murphy's little girls watching Laura and Murphy slaughter the $\operatorname{ram}(\mathrm{p} .244)$.

The ram lay in the dust twitching. Laura put down her gun and was on the dead creature at once with one knee pressed to its side. I saw her knife and Murphy's as they started to deal with carcass. I couldn't stand the sight of it. The little girls were watching. If Mrs. Murphy had not been in hospital, she too would have hovered there. An eager angel of death.

Andrea deliberately reads this image as an echo of the sacrifice of the ram by Abraham, in place of his son with Mrs. Murphy as an absent angel of death. This patriarchal image of sacrifice is also interpreted by Andrea as a possible suicide attempt by Laura. Or at least that is her rationalization, for the image is also an overturning of her request for an abortion (another recapitulation of Laura's relationship with Andrea's mother, for Eva too asked Laura for an abortion). 
At the end of the novel Laura reached an understanding at the cost of selfsacrifice. She sacrifices her world with Andrea, which has been beside, not outside, the law. Therefore, Andrea's vision shifts from a totally enclosed economy of the male gaze, from desire kept entirely within the family-not just because of her relationship with her brother, but because her relationship with Laura is in some ways a rewriting of her mother's relationship with Laura-to a quite different female world in which desire is repressed: the healthful establishment of Hilde and Irma.

Laura and Andrea's relationship begins with what Andrea sees as a betrayal "here I am crying on this big comfortable bed because I have been unfaithful to my brother!" (p.80). In distinction to Andrea's internalized law of faithfulness, Laura offers a message of tolerance, which is obviously part of a world which can only exist outside the law. Laura sees herself and Andrea within a world of passion which is quite separate from the conventional world of mechanical marriage (p.19). At the beginning of this idyll, Laura feels that she can, within her farm, circumvent the rules that pre-scribe relationships, that order love, that dominate sexuality "surely" there can be no laws about love." (p.94). Within this narrative, the world of marriage intrudes much more through the existance of the Murphy family, who haunt Laura with their feckless ways and provide a silently judging audience of children. The farm is no heaven for the Murphys, for it encloses them and is haunted by the multiplying Murphy children. At the end of the novel, however, some kind of symbolic rapprochement seems to take place, as Andrea's departure coincides with Mrs. Murphy's death, and desire is seen to transcend the divisions between hetero and other sexualities (p.259). 
However, this sense of connection through sexuality is transient, and ultimately serves only to emphasize Laura's loss. The novel's final words stress the ultimate enclosure of desire within the heterosexual economy, within the naming of loss (p.260). The male foal is the final image of birth in the novel, which ends without depicting the birth of the child that Andrea carries.

The narrator, the Laura figure, discovers that she is in the hotel room where the Andrea figure has committed suicide. To some extent this story is a comment on the playing out of fictional lives. Palonimo is a final shattering of Laura's world of sexual freedom. The story is centered on libation, which is linked to the sacrifice of the ram (another offering to the gods) within.

Palonimo, Laura's libation is linked to fruitfulness of her farm, as well as to her relationship with Andrea. Palonimo offers the posibility of two opposed readings: either a celebration of female desire outside the law, or a traggedy of loss and containment.

The narrative embeding within Palonimo also seems an echo of the interplay between the freedom of desire and the constriction of the law. Apart from the enclosure on the narrative between Laura's two unsent letters, readers are presented with the shifts between Laura and Andrea's narating voices, the reconstruction of Laura and Eva's relationship (partly through Eva's own voice in her letter), Andrea's retrospective account of her attachment to Christopher, Laura's cardboard diary, and even the symbolic framing of the whole narrative within Death in Venice. This narrative method offers, symbolically, both the safe enclouse of Laura's farm within which love and desire might flourish, and the tangled pressure of social boundaries which constrict such freedom. 
To some extent, this novel is a comment on the playing out of fictional lives (p.109):

It is disconcerting being the subject of someone's fiction. To be the subject might be quite unusual but it is not usuallly known or realized by the person who is the subject.

\section{CONCLUSION}

A great deal of recent criticism and theory has engaged in a debate over postmodernism. The exact nature of the postmodern was the fashionable debating topic of the 1980s and the fashionable topic of the 1990s at present seems to be the consequences of postmodernism for both social and cultural criticism. Postmodernism has been used as a category to encompass everything from changes in philosophical perspectives to changes in architecture. Within literary theory, the postmodern has come to be associated with the kind of self-conscious fiction associated with writers like Borges, Calvino, DeLillo (see Hutcheon, 1988). The postmodern involves a dismantling of categories which have traditionally allowed certain conceptual generalizations to be made and this makes it particularly difficult to enter into any methodological arguments over its nature or concerns. Tion Elizabeth Jolley has come from feminism. Feminist theory has many links with the theoretical procedures of postmodernism, but it has at the same time often pointed to the problematical position of the politics of gender, even of the concept of 'Woman', within a grat deal of postmodern theory (Nicholson, 1990). In literary studies, it has gradually recognized that the idea of postmodern fiction has tended to exclude women writers, both those who could be seen as sharing some of the concerns and technique of the male members of the postmodernist fiction canon, and those who are excluded from trendy critical 
attention because they are seen as working outside of such areas. Elizabeth Jolley may offer a new insight concerning the issue. Jolley's work is connected to a variety of political and theoritical issues, which require changing critical approaches for their exploration. The 'pure' literary evalution of humanist criticism tends to produce an oeuvre which matches the 'fond grandmother' public icon: comforting and unchalleging. In writting about Jolley, there is perhaps a need to recognize the doubleness examplified in a passage like the following from "Woman in a Lampshade" where Jasmine Tredwell sees a hitchhiker while she driving to her farm, in an effort to overdome her writer's block. He is at once her conjured-up Muse, a person, a sign, a pattern of words, and a projection of desire.

She saw the young man standing in the dark. He seemed to be leaning rather than standing, the storm holding him up in its force. He was an indistinct outline, blurred because of the rain. It was as if he had come into existence simply because someone, hopelessly lost among words, had created him in thoughtful ink on the bloting paper.

Taken as whole, Jolley's work is as heterogeneous in its account of how characters relate to the possibilities of the family as it is about so many issues. However, throught her fiction, Jolley is concerned with the way that family structures are dominant socially and their alternatives have to be constructed painfully and precariously. This aspect of Jolley's work is related to the way her cunstruction of characters has involved a narrative shift away from a psychological orientation. This is clearly not a modernist project, but more a postmodern evaluation of disjunction within narrative. 


\section{REFERENCES}

Asthon, M.C, Paunonen, S.V, Helmes, E and Jackson, D.N. 1998. Kin Altruism, Reciprocal Altruism and the Big Five Personality Factors. Evolution and Human Behavior 19: 153 - 169.

Bouchard, T.J.Jr. 1994. Genes, Environment, and Personality. Science 264: 17001701.

Boyd, B. 1998. Jane, Meet Charles: Literature, Evolution, and Human Nature. Philosophy and Literature 22: 1-30.

Buss, D.M. 1999. Evolutionary and Psychology: The New Science of the Mind. Boston: Allyn and Bacon.

Carrol, J. 1995. Evolution and Literary Theory. Columbia: University of Missouri Press.

Constable, J. 1997. Verse Forms: A Pilot Study in the Epidemiology of Representations. Human Nature 8: 171-203.

Digman, J.M. 1990. Personality Structure: Emergence of the Five-factors Model. Annual Review of Psychology 41: 417-440.

Ekman, P. 1994. Antecendent Events and Emotion Metaphors. In P .Ekman and J.R. Davidson (eds). The Nature of Emotion: Fundamental Questions. New York: Oxford University Press.

Fox, R. 1989. The Search for Society: Quest for a Biosocial Science and Morality. New Brunswich: Rutgers University Press.

Fox, R. 1995. Sexual Conflict in the Epics. Human Nature 6: 135-144.

Hutcheon, L. 1988. Poetics of Postmodernism. New York:

Routledge MacDonald, K. 1995. Evolution, the Five Factor Model, and Levels of Personality. Journal of Personality 63: 525-567.

McCare, R.R. (ed). 1992. The Five Factor Model: Issues and Applications Journal of Personality 60: 175-532.

Nicholson, L. 1990. Feminism/Postmodernism. New York and London: Routledge. 